\title{
Most Quebec medical residents show signs of burnout
}

\author{
Cite as: CMAJ 2018 March 26;190:E372. doi: 10.1503/cmaj.109-5581
}

Posted on cmajnews.com on Mar. 5, 2018.

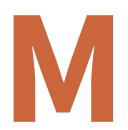

ore than half of Quebec medical residents report signs of burnout, according to a survey conducted by the Fédération des médecins résidents du Québec (FMRQ). Meanwhile, contract talks with the province remain stalled over working hours and pay.

In a survey of 947 FRMQ members, representing about a third of medical residents in Quebec, $54.8 \%$ reported signs of burnout. The survey was based on the Maslach Burnout Inventory, a scale used to measure exhaustion, depersonalization and other signs of burnout in health professionals. Nearly half of respondents $(48.8 \%)$ reported waking up weary before work at least once a week; more than three in five $(64.5 \%)$ said they feel exhausted after work at least once a week.

"The results are really, the only word I have is horrible," said FMRQ President Dr. Christopher Lemieux. "It raises a red flag that the way residents in Quebec are working is not healthy."

In another survey, FRMQ found that residents are working up to 72 hours a week on average, even though their compensation is based on a 35-hour week and other health system employees work 36 hours a week on average. "On top of that, you still have to study for exams, and you have research projects," Lemieux adds. He says something has to give sooner or later. "Medical residents are clearly overloaded and solutions must be found to this situation."

Working hours have been a sticking point in recent contract negotiations between residents and Quebec's Ministry of Health and Social Services. The government wants residents to work more hours and longer shifts, up to 28 hours at a time. "That's illegal, but they're still trying to

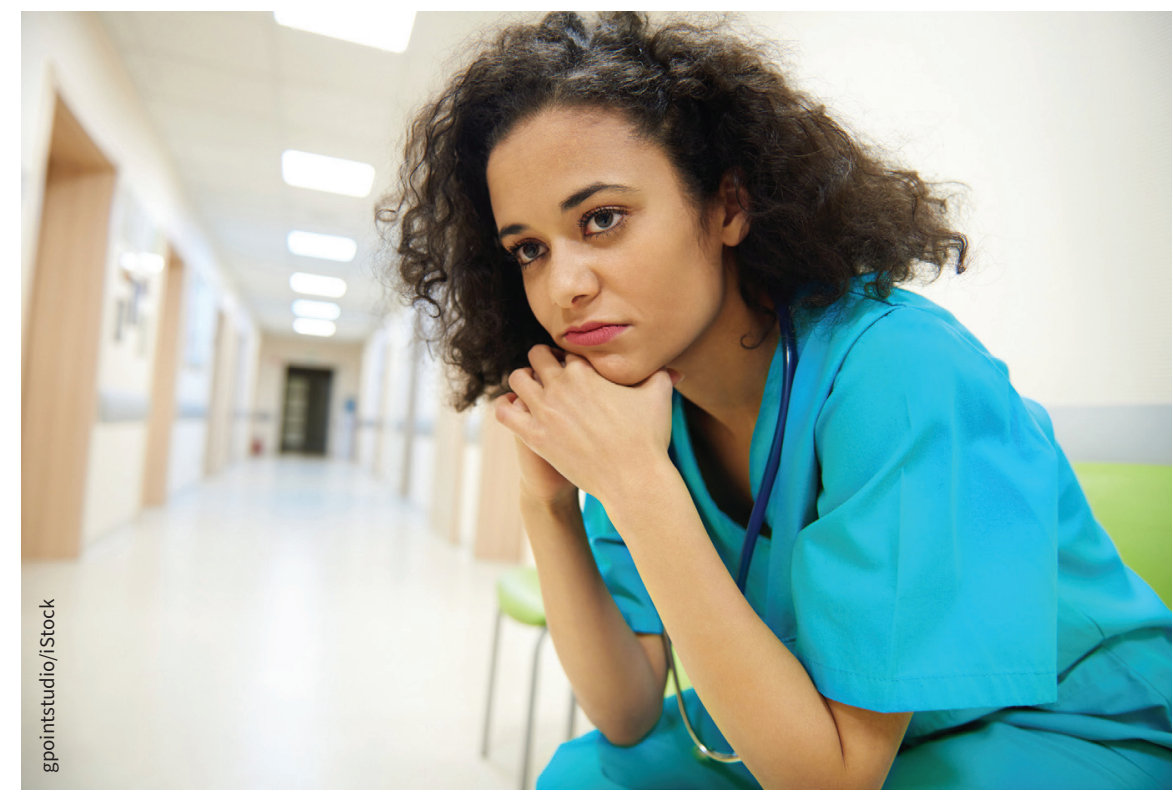

Quebec's government wants medical residents to work more hours and longer shifts, but residents say they are already overloaded.

include that in our collective agreement," says Lemieux. "I wouldn't want to be treated by someone who hasn't slept in more than 25 hours."

The government's attitude throughout negotiations has been "deplorable," adds Lemieux. Residents are asking for a $17 \%$ increase in remuneration, better provisions for parental leave, and more flexible time off to study. In response, "they told us we were lucky to get paid," says Lemieux.

In early February, more than $97 \%$ of the province's four medical resident associations voted in favour of a possible general strike. FMRQ is asking the government to return to the bargaining table with negotiators who understand medical residents' reality. "We are still waiting," says Lemieux. "Medical residents want to sign a collective agreement but it has to be a two-way street."
The residents' last collective agreement expired in 2015. In September, they agreed in good faith to a more intensive bargaining agenda, but talks broke down when the government came to the table with an offer that was "virtually unchanged" from a deal it proposed 18 months earlier.

Among other proposals, the government wants international medical graduates to pay $\$ 30000$ a year to pursue a residency in Quebec; currently, Canadian and international graduates pay $\$ 700$ a year and the government covers the rest. "Because the last contract ended three years ago, we have residents who are concerned the government will ask them to pay back $\$ 30000$ a year since the last agreement," says Lemieux. "They're basically asking them to give back their salary."

Lauren Vogel, CMAJ 